University of Nebraska - Lincoln

DigitalCommons@University of Nebraska - Lincoln

Faculty Publications from the Harold W. Manter Laboratory of Parasitology

$4-1988$

\title{
Eimeria from Bats of the World. II. A New Species in Tadarida femorosacca from Sonora, Mexico
}

Donald W. Duszynski

University of New Mexico, eimeria@unm.edu

David W. Reduker

Washington State University

Brent B. Parker

Colorado State University

Follow this and additional works at: https://digitalcommons.unl.edu/parasitologyfacpubs

Part of the Parasitology Commons

Duszynski, Donald W.; Reduker, David W.; and Parker, Brent B., "Eimeria from Bats of the World. II. A New Species in Tadarida femorosacca from Sonora, Mexico" (1988). Faculty Publications from the Harold W. Manter Laboratory of Parasitology. 180.

https://digitalcommons.unl.edu/parasitologyfacpubs/180

This Article is brought to you for free and open access by the Parasitology, Harold W. Manter Laboratory of at DigitalCommons@University of Nebraska - Lincoln. It has been accepted for inclusion in Faculty Publications from the Harold W. Manter Laboratory of Parasitology by an authorized administrator of DigitalCommons@University of Nebraska - Lincoln. 


\title{
EIMERIA FROM BATS OF THE WORLD. II. A NEW SPECIES IN TADARIDA FEMOROSACCA FROM SONORA, MEXICO
}

\author{
Donald W. Duszynski, David W. Reduker*, and Brent B. Parker† \\ Department of Biology, The University of New Mexico, Albuquerque, New Mexico 87131
}

ABSTRACT: Between 1979 and 1980, 104 bats representing 13 species in 4 families were collected in California and New Mexico, U.S.A., and Baja California and Sonora, Mexico, and were examined for coccidia; only 3 (3\%) had oocysts in their feces. Bats examined and their infection rates were: Molossidae: 0 of 12 Tadarida brasiliensis, 1 of 18 (6\%) T. femorosacca; Natalidae: 0 of 1 Natalus stramineus; Phyllostomatidae: 0 of 1 Choeronycteris mexicana, 0 of 2 Leptonycteris sanborni, 0 of 1 Macrotus californicus; Vespertilionidae: 0 of 9 Antrozous pallidus, 0 of 28 Eptesicus fuscus, 0 of 1 Lasionycteris noctivagans, 0 of 3 Lasiurus borealis, 2 of 22 (9\%) L. cinereus, 0 of 1 L. ega, 0 of 5 Pipistrellus hesperus. Sporulated oocysts were only found in T. femorosacca and these represent a new species, Eimeria tadarida n. sp. They are subspheroidal to ellipsoidal, $19 \times 25$ (16$23 \times 20-30) \mu \mathrm{m}$; a micropyle is absent, and fragments within the oocyst may be oocyst residuum or multiple polar bodies. The oocyst wall, $\sim 1.5 \mu \mathrm{m}$, is composed of a mammillated outer layer and smooth inner layer. Sporocysts are ovoidal, $8 \times 12(6-9 \times 10-14) \mu \mathrm{m}$, and have a small Stieda body and a wide substieda body. This is only the 14th eimerian to be described from bats worldwide. Only unsporulated or partially sporulated oocysts of an eimerian were seen in 2 L. cinereus. These measured $28 \times 25(27-29 \times 24-26) \mu \mathrm{m}$ and had a mammillated outer oocyst wall.

From July 1979 through December 1980 bats were collected from various localities in California and New Mexico, U.S.A., and Baja California and Sonora, Mexico; all animals were examined for the presence of coccidian oocysts in their feces. This paper summarizes our findings.

\section{MATERIALS AND METHODS}

Hosts were captured alive in mist nets and killed within a few hours after capture. Procedures for removal of intestines, preserving fecal material, and processing, measuring, and photographing oocysts were as described previously (Duszynski et al., 1982; Stout and Duszynski, 1983). Skeletons, skins, and tissues for isoenzyme analysis for all hosts are permanently deposited in the Museum of Southwestern Biology, UNM. All measurements are in $\mu \mathrm{m}$ with means $\pm 1 \mathrm{SD}$ in parentheses following the ranges.

\section{RESULTS}

Of 104 bats representing 13 species and 4 families from 14 collection localities (Table I) only 3 had large numbers of oocysts in their feces. The study of these oocysts revealed qualitative and quantitative differences between them and oocysts of other Eimeria spp. described from bats.

Received 2 September 1987; revised 6 October 1987; accepted 17 December 1987.

* Present address: Department of Veterinary Microbiology and Pathology, Washington State University, Pullman, Washington 99164.

$\uparrow$ Present address: College of Veterinary Medicine, Colorado State University, Ft. Collins, Colorado 80523 .

\section{Eimeria tadarida n. sp.}

(Figs. 1-4, 8)

\section{Description}

Oocysts subspheroidal (Fig. 1) to ellipsoidal (Fig. 2), wall of uniform thickness $\sim 1.5$, with 2 layers: outer layer mammillated (Fig. 3), $\sim 2 / 3$ of total thickness, inner layer smooth; micropyle absent; 1-3 fragments within oocyst (Fig. 4) that may represent multiple polar bodies or a dispersed oocyst residuum; sporulated oocysts $(\mathrm{n}=$ 100) $20-30 \times 16-23(25.2 \pm 2.1 \times 19.0 \pm 1.2)$, with $\mathrm{L}: \mathrm{W}$ ratio $1.2-1.6(1.3 \pm 0.1)$; sporocysts $(\mathrm{n}=100)$ ovoidal, $10-14 \times 6-9(12.1 \pm 0.7 \times 7.6 \pm 0.9)$, with $\mathrm{L}: \mathrm{W}$ ratio $1.4-1.7(1.6 \pm 0.1)$; Stieda body small, difficult to see with transmitted light or interference contrast microscopy; substieda body apparently present (there is always a clear space below pointed end of sporocyst: Figs. 1, 2, 4), asymmetrical, 2-3× wider than Stieda body; parastieda body absent; sporocyst residuum composed of several small to large globules and granules, sometimes obscuring sporozoites; sporozoites with a large, posterior refractile body. Oocysts were 1,935 days old when measured.

\section{Taxonomic summary}

Diagnosis: Of the 13 valid species of Eimeria previously described from chiropteran hosts (Levine and Ivens, 1981; Duszynski and Barkley, 1985), only Eimeria tomopea Duszynski and Barkley, 1985, Eimeria macyi Wheat, 1975, and Eimeria eumopos Marinkelle, 1968 resemble $E$. tadarida. Oocysts of $E$. tadarida differ from those of E. tomopea by being smaller and lacking a polar body; they also have smaller sporocysts that have a substieda body that E. tomopea lacks, although in both species the Stieda body is difficult to visualize. They differ from those of $E$. macyi by having a residuum and lacking polar bodies; by having larger oocysts with a larger L:W ratio (1.3 vs. 1.1$)$; and by having a substieda body that is $2-3 \times$ wider than the Stieda body vs. one that is the same width. They differ 
TABLE I. Thirteen species of bats representing 4 families taken from 14 collection localities from California, New Mexico, and Baja California and Sonora, Mexico and examined for coccidia.

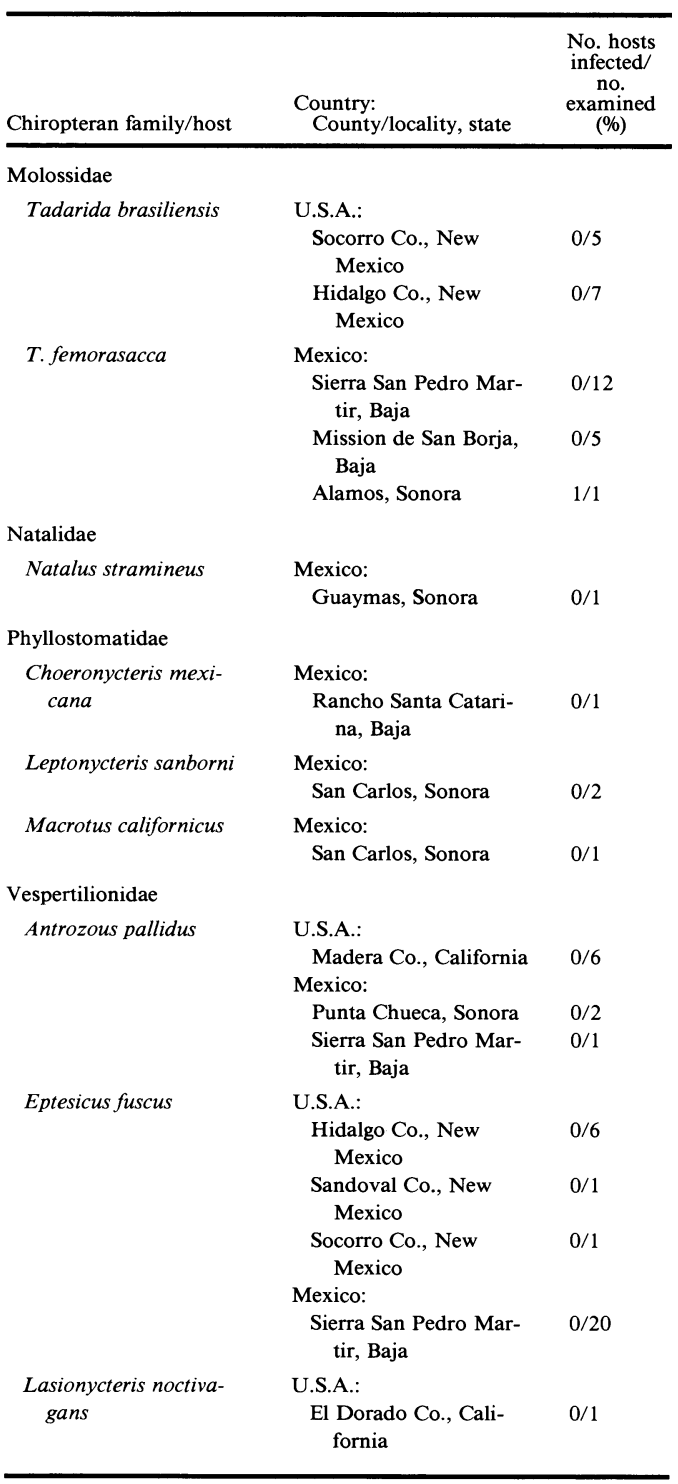

TABle I. Continued.

\begin{tabular}{|c|c|c|}
\hline Chiropteran family/host & $\begin{array}{l}\text { Country: } \\
\text { County/locality, state }\end{array}$ & $\begin{array}{l}\text { No. hosts } \\
\text { infected/ } \\
\text { no. } \\
\text { examined } \\
\text { (\%) }\end{array}$ \\
\hline Lasiurus borealis & $\begin{array}{l}\text { U.S.A.: } \\
\text { Hidalgo Co., New } \\
\quad \text { Mexico }\end{array}$ & $0 / 3$ \\
\hline \multirow[t]{3}{*}{ L. cinereus } & $\begin{array}{l}\text { U.S.A.: } \\
\text { El Dorado Co., Cali- } \\
\text { fornia }\end{array}$ & $0 / 3$ \\
\hline & $\begin{array}{l}\text { Hidalgo Co., New } \\
\text { Mexico } \\
\text { Mexico: }\end{array}$ & $1 / 8(12.5)$ \\
\hline & $\begin{array}{l}\text { Sierra San Pedro Mar- } \\
\text { tir, Baja }\end{array}$ & $1 / 11(9.0)$ \\
\hline L. ega & $\begin{array}{l}\text { Mexico: } \\
\text { Mission de San Borja, } \\
\text { Baja }\end{array}$ & $0 / 1$ \\
\hline \multirow[t]{4}{*}{ Pipistrellus hesperus } & Mexico: & \\
\hline & Guaymas, Sonora & $0 / 3$ \\
\hline & $\begin{array}{l}\text { Sierra San Pedro Mar- } \\
\text { tir, Baja }\end{array}$ & $0 / 1$ \\
\hline & $\begin{array}{l}\text { Valle de Trinidad, } \\
\text { Baja }\end{array}$ & $0 / 1$ \\
\hline 4 families, 13 species & 14 localities & $3 / 104$ (1) \\
\hline
\end{tabular}

from those of E. eumopos by lacking polar bodies and being much smaller $(25 \times 19$ vs. $35 \times 28)$; by having a thinner outer wall that is mammillated, not pitted; and by having sporocysts with a substieda body that E. eumopos lacks.

Type host: Tadarida femorosacca (Merriam), pocketed free-tail bat, Museum of Southwestern Biology, Division of Mammals, MSB \#53835 (female), J. Haydock \#282, 27 October 1980.

Type locality: Mexico. Sonora: $19.3 \mathrm{~km}$ E Alamos by road Rio Cuckujaqui.

Site of infection: Unknown. Oocysts recovered from feces.

Etymology: The nomen triviale is derived from the generic name of the host.

\section{Eimeria sp.}

(Figs. 5-7)

Oocysts subspheroidal (Fig. 5), wall of uniform thickness $\sim 2.0$, with 2 layers: outer layer mammillated (Fig. 6, insert), $\sim 3 / 4$ of total thickness, inner layer smooth (Fig. 6). Although no sporulated oocysts were seen, a few abnormally sporulated forms (Fig. 7) clearly show

FIGURES 1-7. Photomicrographs of sporulated oocysts of Eimeria tadarida n. sp. collected from the feces of Tadarida femorosacca (Figs. 1-4) and of unsporulated oocysts of an eimerian collected from the feces of Lasiurus cinereus (Figs. 5-7). $\times 1,600$. 1. Subspheroidal oocyst; note striated appearance of wall. 2. More ellipsoidal oocyst; note the clear area (arrows) seen in these sporocysts and in those in Figures 1 and 4, that is probably a substieda body. 3. Mammillated surface of outer oocyst wall (NIC). 4. Oocyst with what is either multiple polar bodies or fragments of a residuum (arrows). 5. Subspheroidal oocyst. 6. Outer wall separating from smooth inner wall of partially sporulated oocyst; insert shows mammillated outer layer of oocyst wall (NIC). 7. Broken, partially sporulated oocyst with what may be a parastieda body (arrow) in one of the sporocysts. 


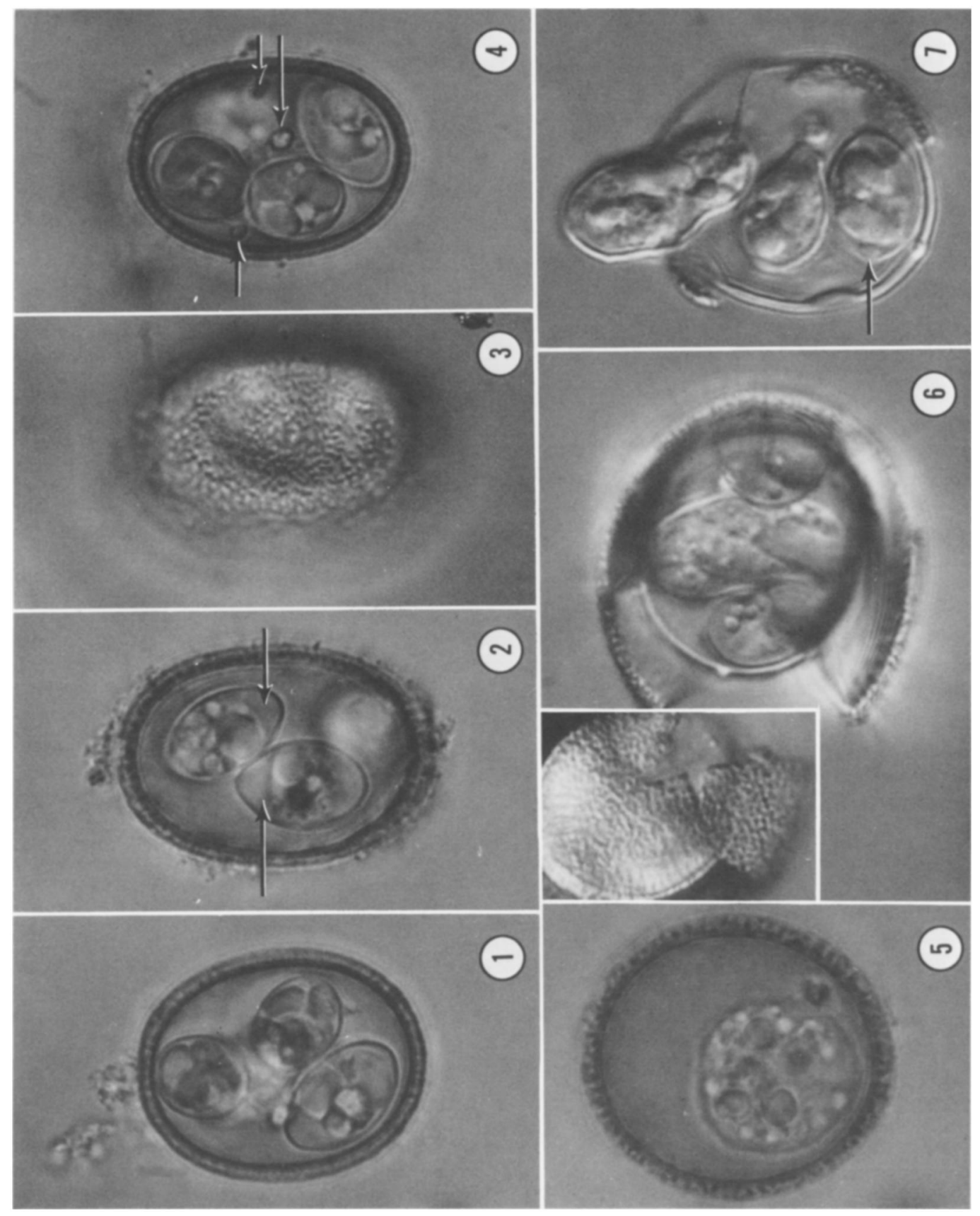




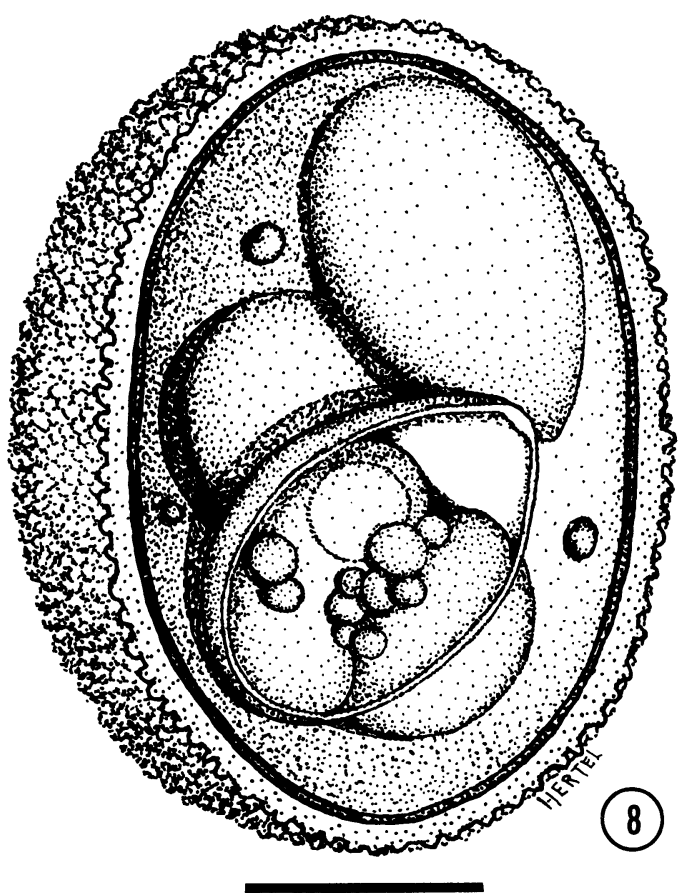

FIGURE 8. Line drawing of a sporulated oocyst of Eimeria tadarida. Bar $=5 \mu \mathrm{m}$.

that this species is an eimerian. Unsporulated oocysts were $28 \times 25(27-29 \times 24-26)$ with L:W ratio 1.1 .

\section{Taxonomic summary}

Diagnosis: This form is similar in either size or shape to E. eumopos, E. macyi, E. tomopea, and Eimeria zakirica Mussev, 1967. It differs from the first 3 by being smaller than $E$. eumopos $(35 \times 28)$ and $E$. tomopea $(31 \times 25)$ and larger than $E$. macyi $(19 \times 18)$. It differs from $E$. eumopos and $E$. tomopea by being less ellipsoidal (L:W 1.1 vs. 1.2-1.4). It is similar to all 3 species, however, by having a highly sculptured outer wall that appears striated in optical cross section. Although similar in size and shape to E. zakirica, the 2 differ because $E$. zakirica has a thin, smooth 1-layered oocyst wall.

Type host: Lasiurus cinereus (Beauvois, 1796), hoary bat, Museum of Southwestern Biology, Division of Mammals, MSB \#42509 (male), D. A. Goebel \#38, 16 June 1980.

Type locality: U.S.A. New Mexico: Hidalgo Co., $27.3 \mathrm{~km} \mathrm{~S}, 10.6 \mathrm{~km} \mathrm{E}$, Animas.

Other host and locality: Lasiurus cinereus, MSB \#43048 (male), T. L. Best \#8622, 8 July 1980, Mexico, Baja California, Parque Nacional, Sierra de San Pedro Martirs.

\section{DISCUSSION}

The mammalian order Chiroptera is second only to the rodents in terms of species diversity and numbers. However, in contrast to rodents, few Eimeria spp. have been described from bat hosts. For example, only 14 valid Eimeria species have been described from 14 species of bats, $1.5 \%$ of the living bat host species (see Duszynski and Barkley, 1985, for review). There are at least 2 possible explanations for this. First, as pointed out by Ubelaker et al. (1977), the paucity of $E i$ meria spp. described from bats reflects the fact that few people have examined bats for intestinal coccidia. A second explanation is that bats, as a group, seem not to be regularly parasitized by monoxenous coccidians. In the few surveys that have been done, only small numbers of bats are ever found to be discharging oocysts. For example, Marinkelle (1968) found only 2 of 400 bats ( 23 species) in Colombia to have oocysts in their feces when examined. Similarly, here we found only 3 of the 104 bats (13 species) we examined from Mexico and the western U.S.A. to be actively discharging oocysts. The mechanism that drives this low rate of infection simply may be the feeding habits of the hosts. Most bats (e.g., molossids, vespertilionids) are insectivores and insects on the wing do not seem to be particularly good concentrating mechanisms for oocysts. Bats that eat other things such as fruit, nectar, or pollen (e.g., phyllostomatids) do not seem to be any more often infected than insectivores, although more survey work needs to be done before this idea can be critically examined. Likewise, Antrozous, a bat with unusual eating habits and known to forage on the ground and eat scorpions and crickets, also is not often infected with coccidians. Thus, regardless of diet, bats have never been found to be heavily infected with coccidians. Host genetic factors (e.g., high chromosomal variability) may contribute to this phenomenon (see Duszynski, 1986). Finally, it is interesting to note that $2 \mathrm{~L}$. cinereus collected in different localities were discharging oocysts (Eimeria sp., above) that probably represent the same species.

Based on characteristics of the oocyst wall (thickness and texture), Duszynski and Barkley (1985) hypothesized at least a diphyletic origin for Eimeria spp. infecting bats. The 3 eimerians previously described from New World vespertilionid and molossid bats (E. macyi, E. tomopea, E. eumopos) have thick and mammillated oocyst walls, whereas the 6 eimerians described from African and Old World vespertilionids and molossids (E. dukei, E. levinei, E. nyctali, $E$. vajsovi, E. vespertilii, E. zakirica) have smoothwalled oocysts. Eimeria tadarida and Eimeria sp., which parasitize a New World molossid and 
vespertilionid, respectively, both have mammillated oocyst walls, thus supporting this hypothesis.

\section{ACKNOWLEDGMENTS}

We are indebted to the following colleagues at UNM and elsewhere for their help in catching bats and in various other aspects of this work: Dr. J. Bandoli, Dr. T. L. Best, C. Bindl, A. S. Christmas, Dr. S. B. George, D. A. Goebel, Dr. D. J. Hafner, J. Haydock, Dr. C. A. Speer, Dr. C. A. Stout, and, especially, Dr. T. L. Yates. Thanks are also due L. Hertel who did the line drawing. This work was supported, in part, by the Biology Graduate Research Allocation Committee, UNM.

\section{LITERATURE CITED}

DUSZYNSKI, D. W. 1986. Host specificity in the coccidia of small mammals: Fact or fiction? In Advances in protozoological research, M. Bereczky (ed.). Symposia Biologica Hungarica, Vol. 33. Akademiai Kiado, Budapest, pp. 325-337.

- AND L. J. BARKLEY. 1985. Eimeria from bats of the world: A new species in Tomopeas ravus from Peru. Journal of Parasitology 71: 204-208.

, G. EAStham, AND T. L. Yates. 1982. Eimeria from jumping mice (Zapus spp.): A new species and genetic and geographic features of $Z$. hudsonicus luteus. Journal of Parasitology 68: 1146-1 148.

Levine, N. D., AND V. Ivens. 1981. The coccidian parasites (Protozoa, Apicomplexa) of bats. In Parasitological topics: A presentational volume to $P$. C. C. Garnham, F.R.S., on the occasion of his 80th birthday, E. U. Canning (ed.). Society of Protozoologists, Special Publication No. 1, pp. 170176.

MARinkelle, C. J. 1968. Eimeria eumopos n. sp. from a California bat Eumops trumbulli. Journal of Protozoology 15: 57-58.

Stout, C. A., AND D. W. Duszynski. 1983. Coccidia from kangaroo rats (Dipodomys spp.) in the western United States, Baja California, and northern New Mexico with descriptions of Eimeria merriami sp. n. and Isospora sp. Journal of Parasitology 69: 209-214.

UbelaKer, J. E., R. D. SPeCian, AND D. W. Duszynski. 1977. Endoparasites. In Biology of the New World family Phyllostomatidae, Part II, R. J. Baker, J. K. Jones, and D. C. Carter (eds.). Special Publication No. 13 of the Museum, Texas Tech University Press, Lubbock, pp. 7-56. 